\title{
Diversity and Chemical Composition of Weeds in Sand-Filled Mangrove Forest at Eagle Island, Niger Delta, Nigeria
}

\author{
Aroloye Ofo Numbere \\ Department of Animal and Environmental Biology, University of Port Harcourt, Port Harcourt, Nigeria \\ Email: aroloyen@yahoo.com
}

How to cite this paper: Numbere, A.O. (2020) Diversity and Chemical Composition of Weeds in Sand-Filled Mangrove Forest at Eagle Island, Niger Delta, Nigeria. American Journal of Plant Sciences, 11, 994-1007.

https://doi.org/10.4236/ajps.2020.117071

Received: June 9, 2020

Accepted: July 10, 2020

Published: July 13, 2020

Copyright ( 2020 by author(s) and Scientific Research Publishing Inc. This work is licensed under the Creative Commons Attribution International License (CC BY 4.0).

http://creativecommons.org/licenses/by/4.0/

\begin{abstract}
Mangroves are habitat specific and grow mainly in swampy soil, but due to anthropogenic activities (e.g. sand mining) other species had encroached into their habitat. It is thus hypothesized that change in species diversity will lead to change in soil chemistry. In a $40 \mathrm{~m} \times 90 \mathrm{~m}$ plot, diversity index $(H)$ and importance value $\left(I_{v}\right)$ of weed were estimated. Soil and weed samples were collected and analyzed for total hydrocarbon content (THC), Zinc (Zn), Lead $(\mathrm{Pb})$ and Cadmium $(\mathrm{Cd})$. All samples were analyzed with atomic absorption spectrophotometric method using the HACH DR 890 calorimeter (wavelength $420 \mathrm{~nm}$ ). The result shows that swampy soils were more acidic (3.1 3.5) than sandy soils $(4.2-4.7)$. Swampy soil was also more saline and thus has higher conductivity $(8320-9880 \mu \mathrm{S} / \mathrm{cm})$ than sandy soil $(4320-5650$ $\mu \mathrm{S} / \mathrm{cm})$. Mangrove swamp had higher total organic carbon (TOC) $(2.25 \%-$ $3.41 \%)$ than sandy soil $(0.12 \%-0.21 \%)$. There was a significant difference in THC and heavy metals in soil $\left(\mathrm{F}_{8,63}=2.04, \mathrm{P}<0.05\right)$, but there was no significant difference in THC and heavy metals in plant species $\left(\mathrm{F}_{8,63}=247.0, \mathrm{P}>\right.$ 0.05). Concentration of THC and heavy metal was higher in plant than in soil. Reissantia indica, an aquatic weed, had the highest concentration of THC in root soil. A total of fifteen (15) weed species were identified, out of which Mariscus longibracteatus had the highest diversity $(-0.366)$ followed by Mariscus ligularis $(-0.339)$ and Paspalum vaginatum $(-0.270)$. Similarly, M. longibracteatus had the highest importance value in the study site $\left(I_{V}=58.24\right)$. This result implies that the presence of weed species in mangrove forest is an indicator of human disturbance of the ecosystem. It also means that the weeds were bioaccumulating THC and heavy metals present in the soil.
\end{abstract}




\section{Keywords}

Heavy Metals, Mangrove Weed, Soil, Species Diversity, Sand Fill, Swamp

\section{Introduction}

Mangroves are habitat specific and inhabit swampy and saline environment [1] [2] [3] [4]. Mangrove weed are plants that are found in disturbed mangrove forest such as reclaimed land, sand filled and dredged sites [5]. Weeds are unwanted plants that grow in any place that is favorable for their growth and survival such as water, soil, tree trunk, wall of building and coastal soil [6]. Aquatic weeds grow in water and have effects on coastal environment [7]. For instance these weeds can change the ecology of the area by supplying or utilizing soil nutrients, which may be detrimental to the native species [8] [9]. Weed can affect fish spawning capability by obstructing breeding grounds [10]; they can also increase the heavy metal concentration through the actions of their root, which break up the parent soil to expose more metals. Humans also introduce seeds of weed into the mangrove forests, which embed in the soil and grow. Growth of weed in disturbed mangrove forests converts indigenous mangrove soil to sandy soil. The weed species are able to grow at the fringes and perimeters of the mangrove forest that had been cut down for the purpose of creating access way for pipelines [11]. This is because the pipeline route is usually covered with sandy soils brought elsewhere, which further introduce and accelerate weed growth [12]. Furthermore, the sand filling of mangrove forest also changes the soil chemistry when muddy soils are converted to sandy soil. Change in soil chemistry can lead to increased heavy metal load, which has ripple effect on the aquatic environment [13]. For instance, fishes and other aquatic organisms bioaccumulate the excess heavy metals, which they pass on to humans who feed on them [14] [15]. Over the years several questions had been asked as to the role played by the mangrove weeds, which are often found in degraded mangrove forests. Do these foreign plants growing in mangrove forest play positive and/or negative roles? These questions are yet to be addressed. However, it is revealed by previous studies that in agricultural farms weeds can act as habitat for insect pollinators e.g. butterfly, grasshoppers, praying mantis beetles etc., which is a positive role for nearby plants. Nevertheless, weeds can play negative role by acting as nesting sites for pathogenic organisms such as mosquitoes, black fly etc. [16]. The growth of the weeds near the mangrove forest can also bring in destructive herbivores such as locust, caterpillars and insect pests that feed on leaves. In the Niger Delta there are limited studies to address these questions. Therefore, this study is aimed at investigating the diversity of weed and other plant species found in sand filled mangrove forests, and to determine the concentration of some heavy metals in soil and plant. The objectives of this study are: 1) to determine the diversity index $(H)$ and importance value $\left(I_{v}\right)$ of the 
weed species 2) to determine the THC and heavy metal concentration in both soil and plant, and 3) to compare the THC and heavy metal concentration in plant and soil.

\section{Materials and Methods}

\subsection{Description of Study Area}

The study area is an abandoned sand dump located at Eagle Island ( $4^{\circ} 47.317^{\prime}$ and E $6^{\circ} 58.593^{\prime}$ ), directly behind the Rivers State University (Figure 1 ). The area has a warm and humid climate with two seasons, dry and wet seasons [17]. The soil of the area is between sandy to muddy, and also whitish to dark brown in color [18]. The area was once a mangrove forest, but was cut down to make way for sand mining five years ago. At the end of the sand mining activity the area was later abandoned to its fate. The company that operated the sand mine left the site with heaps of white sand still on the ground surface [19]. This abandoned sand became a plat form on which a variety of weed and other plant species grow over the years. These species are plants that naturally cannot grow in swampy soil but because of the conversion of the sand from swampy to sandy soil weeds do proliferate. Moreover, the site is surrounded by a river channel which brings in sediments and seeds of plants during high tide. At the edges of the sand dump are heaps of mangrove soils placed to prevent the entry of water during high tide.

\subsection{Sample Collection}

In an area measuring $3600 \mathrm{~m}^{2}$ (i.e. $40 \mathrm{~m} \times 90 \mathrm{~m}$ ) eight plots were delineated from where weed and soil samples were randomly collected (Figure 2). The plants

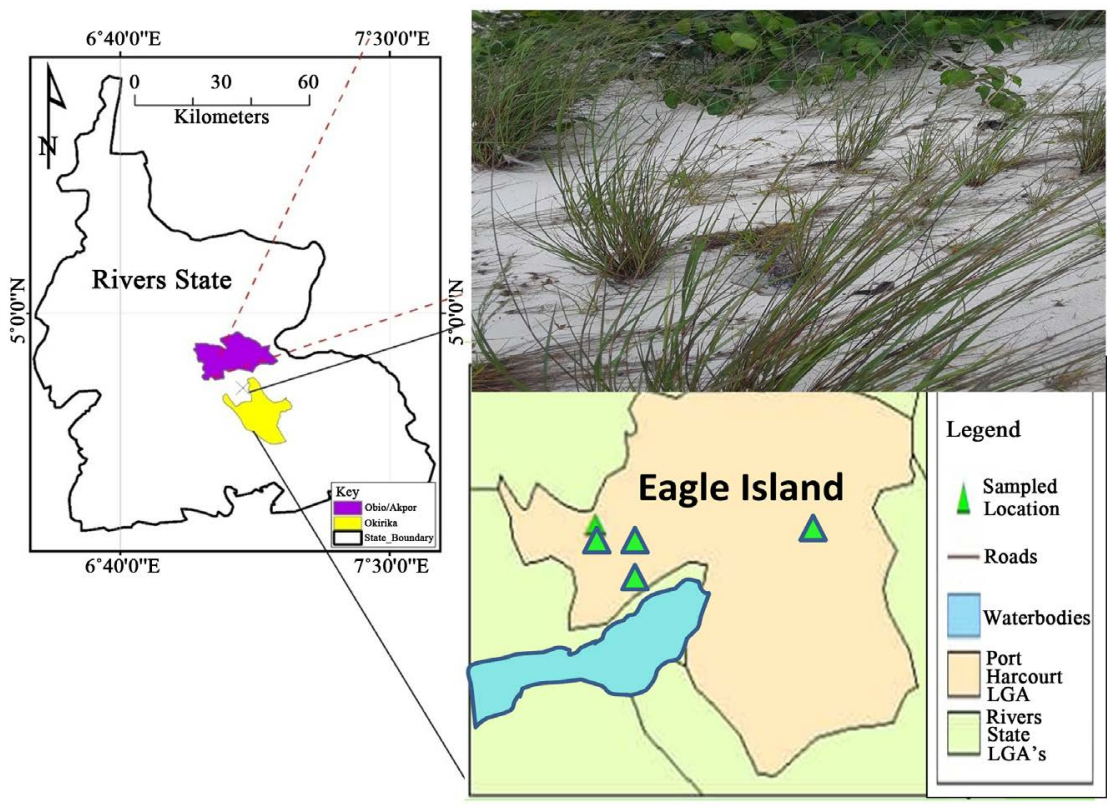

Figure 1. Map of study area showing the sand fill area colonized by weeds at Eagle Island, Niger Delta. 


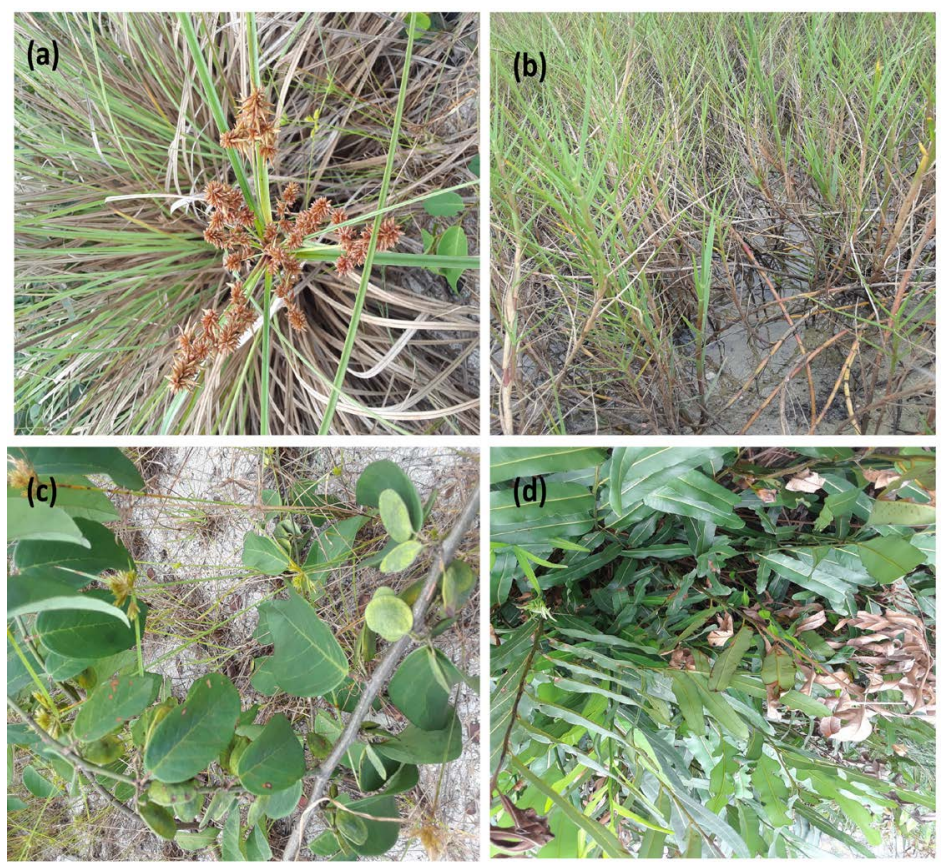

Figure 2. The four most dominant plant species growing in sand filled mangrove forest at Eagle Island, Niger Delta (a) Mariscus ligularis (b) Paspalum vaginatum (c) Reissantia indica (d) Acrostichum aureum.

were counted and each weed samples collected and placed in a cellophane bag. Similarly soil samples were collected beneath the plant root $5 \mathrm{~cm}$ below the soil with a soil augur and also placed in a cellophane bag. All the samples were put in a cooler and transported to the laboratory for physico-chemical analysis.

\subsection{Physico-Chemical Analysis}

In other to determine the soil chemistry of the study area, physico-chemical analysis of soil were done for the following parameters: $\mathrm{pH}$, conductivity, total hydrocarbon (THC), total organic content (TOC), Nickel (Ni), Lead (Pb), Chromium (Cr), Magnesium (Mg), Potassium (K), Sodium (Na), Calcium and (Ca), while for the plant sample the following were parameters were analyzed: $\mathrm{Cd}, \mathrm{Pb}$, $\mathrm{Zn}$ and THC using standard laboratory procedures described below.

\subsection{Procedures of THC Analysis}

It involved the use of spectrophotometric method using the HACH DR 890 calorimeter (wavelength $420 \mathrm{~nm}$ ). The samples were crushed and $2 \mathrm{~g}$ of the crushed sample was weighed into a glass beaker and $20 \mathrm{ml}$ of hexane was added, and with the aid of a glass rod, the mixture was homogenized by stirring. Afterwards, the sample was filtered in a glass funnel packed with cotton wool, silica gel and anhydrous sodium sulphate. After this, $10 \mathrm{ml}$ of the filtered organic extract was transferred into a $10 \mathrm{ml}$ sample curvet and inserted into the calorimeter. The detection limit for THC is $0.01 \mathrm{mg} / \mathrm{l}$. The above method followed the procedures of [20]. 


\subsection{Procedures of Heavy Metal Analysis}

Heavy metal extraction followed the example of [21]. Aliquots of $0.25 \mathrm{~g}$ of air dried sediment samples were weighed into a Teflon inset of a microwave digestion vessel and $2 \mathrm{ml}$ concentrated (90\%) nitric acid (Sigma-Aldrich, Dorset, UK) were added. The metals were extracted using a microwave accelerated reaction system (MARS Xpress, CEM Corporation, Matthews, North Carolina) at $1500 \mathrm{~W}$ power (100\%), ramped to $175^{\circ} \mathrm{C}$ in $5.5 \mathrm{~min}$, held for $4.5 \mathrm{~min}$, and allowed to cool down for $1 \mathrm{~h}$. The cool digest solution was filtered through the Whatman 42 filter paper and made up to $100 \mathrm{ml}$ in a volumetric flask by adding de-ionized water. All chemicals and reagents used were of analytical grade and of highest purity possible. Analytical blanks were prepared with each batch of the digestion set and analyzed (one blank for every set of 6 samples) in the same way as the samples. The detection limit for the three metals analyzed in $\mathrm{mg} / \mathrm{l}$ i.e. Zinc, Cadmium and Lead is $0.001,0.001$ and 0.002 respectively.

\subsection{Procedures of Physico-Chemical Analysis}

The $\mathrm{pH}$ and conductivity were measured using Sper Scientific 86003A multi parameter meters with probes calibrated with standard solutions. Total Organic Carbon (TOC) was determined using Walkey-Black titrimetric method.

\subsection{Identification of Weed Species}

The weeds collected from the site were sent to the laboratory and identified using a handbook of West African weed by [7]. The weeds were identified based on the shape of the leaves, color, seeds, inflorescence and fruit produced.

\subsection{Statistical Analysis}

An analysis of variance (ANOVA) was conducted to determine whether there was a significant difference in THC and heavy metal concentration in soil and plant [22]. Bar graphs were then used to illustrate the significance and difference in concentration in plant and soil. All analyses were done in [23].

\subsection{Data Analysis}

The stand basal area, $\mathrm{G}$, measured in $\mathrm{m}^{2} / \mathrm{ha}$, (Equation (1)) refers to the summation of all individual basal areas per unit ground area [24]. Where, $g_{i}\left(\mathrm{~m}^{2}\right)$ is the basal area of a single stand (Equation (2)), while 25 (400) is the plot size of the 40 $\mathrm{m} \times 90 \mathrm{~m}\left(3600 \mathrm{~m}^{2}\right)$ main plot, and a $5 \mathrm{~m} \times 5 \mathrm{~m}\left(25 \mathrm{~m}^{2}\right)$ sub-plot, as the conversion factor to 1 hectare [25].

$$
\begin{gathered}
G=\sum_{i=1}^{N} g_{i} \times 25(3600) \\
g=\pi \times\left(\frac{d b h}{2}\right)^{2}
\end{gathered}
$$

The importance value, $I_{V}$ is a quantitative parameter used to show the significance of each species within a stand. It is a summation of density, frequency 
and dominance (Equations (3), (4), (5) and (6)). The importance value $\left(I_{v}\right)$ was calculated using the formula of [24].

$$
\begin{gathered}
I_{V}=\text { Relative Density } \pm \text { Relative Frequency } \pm \text { Relative Dominance } \\
\text { Relative Density }(\%)=\frac{\text { no of individuals of species }\left(\mathrm{N} \cdot \mathrm{ha}^{-1}\right)}{\text { total number of individuals }\left(\mathrm{N} \cdot \mathrm{ha}^{-1}\right)} \times 100 \\
\text { Relative Frequency }(\%)=\frac{\text { frequency of species }(\mathrm{n})}{\text { total number of species }\left(\mathrm{N} \cdot \mathrm{ha}^{-1}\right)} \times 100 \\
\text { Relative Dominance }(\%)=\frac{\text { total basal area of species }}{\text { Basal area of all species }(G)} \times 100
\end{gathered}
$$

To determine the species diversity, the Shannon Index $(H)$ was used (Equation (7)), and is based on natural logarithm which considers low and high diversity species based on abundance of species. Higher values of diversity index imply higher biodiversity of that plant species and vice versa [26]. Species diversity is used for this study because it serves as an indicator of human disturbances [27].

$$
H=\sum_{I=1}^{1} p_{i} \ln \left(p_{i}\right)
$$

where,

$$
\begin{aligned}
& H=\text { Shannon diversity index; } \\
& \sum_{I=1}^{1} \text { = summation; } \\
& \ln =\text { natural logarithm. }
\end{aligned}
$$

\section{Results}

\subsection{Physico-Chemical Analysis}

Result (Table 1) of the physico-chemistry of the study area shows that swampy soils are more acidic $(3.10$ - 3.50) than sandy soil $(4.20$ - 4.70) that harbor the weed species. Swampy soils are also more saline and thus have higher ability to conduct electrons $(8320.00-9880.00 \mu \mathrm{S} / \mathrm{cm})$ as compared to sandy soil $(4320.00$ - $5650.00 \mu \mathrm{S} / \mathrm{cm}$ ). Mangrove swamp has higher total organic carbon (TOC) $(2.25 \%-3.41 \%)$ than sandy soil $(0.12 \%-0.21 \%)$. Furthermore, swampy soil has more concentration of heavy metals i.e. $\mathrm{Ni}, \mathrm{Pb}$ and $\mathrm{Cr}$. In addition, swampy soils are also high in $\mathrm{K}$ and $\mathrm{Na}$ [28]. In contrast, sandy soil had more $\mathrm{Mg}$ content.

Table 1. General physico-chemistry of soil samples collected randomly from study area at Eagle Island, Niger Delta Nigeria.

\begin{tabular}{ccccccccccccc}
\hline $\begin{array}{c}\text { Sample } \\
\text { Identity }\end{array}$ & $\mathrm{pH}$ & $\begin{array}{c}\text { Conductivity } \\
(\mu \mathrm{S} / \mathrm{cm})\end{array}$ & $\begin{array}{c}\mathrm{THC} \\
(\mathrm{mg} / \mathrm{kg})\end{array}$ & $\begin{array}{c}\mathrm{TOC} \\
(\%)\end{array}$ & $\begin{array}{c}\mathrm{Ni} \\
(\mathrm{mg} / \mathrm{kg})\end{array}$ & $\begin{array}{c}\mathrm{Pb} \\
(\mathrm{mg} / \mathrm{kg})\end{array}$ & $\begin{array}{c}\mathrm{Cr} \\
(\mathrm{mg} / \mathrm{kg})\end{array}$ & $\begin{array}{c}\mathrm{Mg} \\
(\mathrm{mg} / \mathrm{kg})\end{array}$ & $\begin{array}{c}\mathrm{K} \\
(\mathrm{mg} / \mathrm{kg})\end{array}$ & $\begin{array}{c}\mathrm{Na} \\
(\mathrm{mg} / \mathrm{kg})\end{array}$ & $\begin{array}{c}\mathrm{Ca} \\
(\mathrm{mg} / \mathrm{kg})\end{array}$ \\
\hline Swamp 1 & 3.10 & 8320.00 & 5.63 & 3.41 & 5.66 & 5.60 & 0.59 & 134.50 & 14.20 & 2389.00 & 4.20 \\
Swamp 2 & 3.50 & 9880.00 & 2.33 & 2.25 & 6.35 & 7.27 & 7.37 & 62.20 & 192.00 & 3528.00 & 18.90 \\
Sand 1 & 4.70 & 4320.00 & 5.50 & 0.12 & 1.04 & 0.41 & $<0.001$ & 315.00 & 10.00 & 625.70 & 82.10 \\
Sand 2 & 4.20 & 5650.00 & 7.84 & 0.21 & 1.19 & 1.78 & 44.87 & 306.10 & 11.90 & 351.60 & 1.60 \\
\hline
\end{tabular}




\subsection{Concentration of THC and Heavy Metals in Soils Collected from Root of Weed Species}

The results for the nine most dominant weed species (Table 2, Figure 3) indicate that there is a significant difference in THC and heavy metal concentration in soil $\left(\mathrm{F}_{8,63}=2.04, \mathrm{P}<0.05\right)$. $R$. indica has the highest concentration of THC in root soil. There was also a significant difference in the concentration among the parameters i.e. THC and heavy metals $(\mathrm{P}<0.05) . \mathrm{Zn}$ and THC had the highest soil concentrations (Table 2). M. longibracteautus had the highest $\mathrm{Zn}(7.67 \pm$ $0.005 \mathrm{mg} / \mathrm{kg}$ ) followed by $A$. areum $(5.79 \pm 0.01)$ and M. ligularis $(5.60 \pm 0.01$
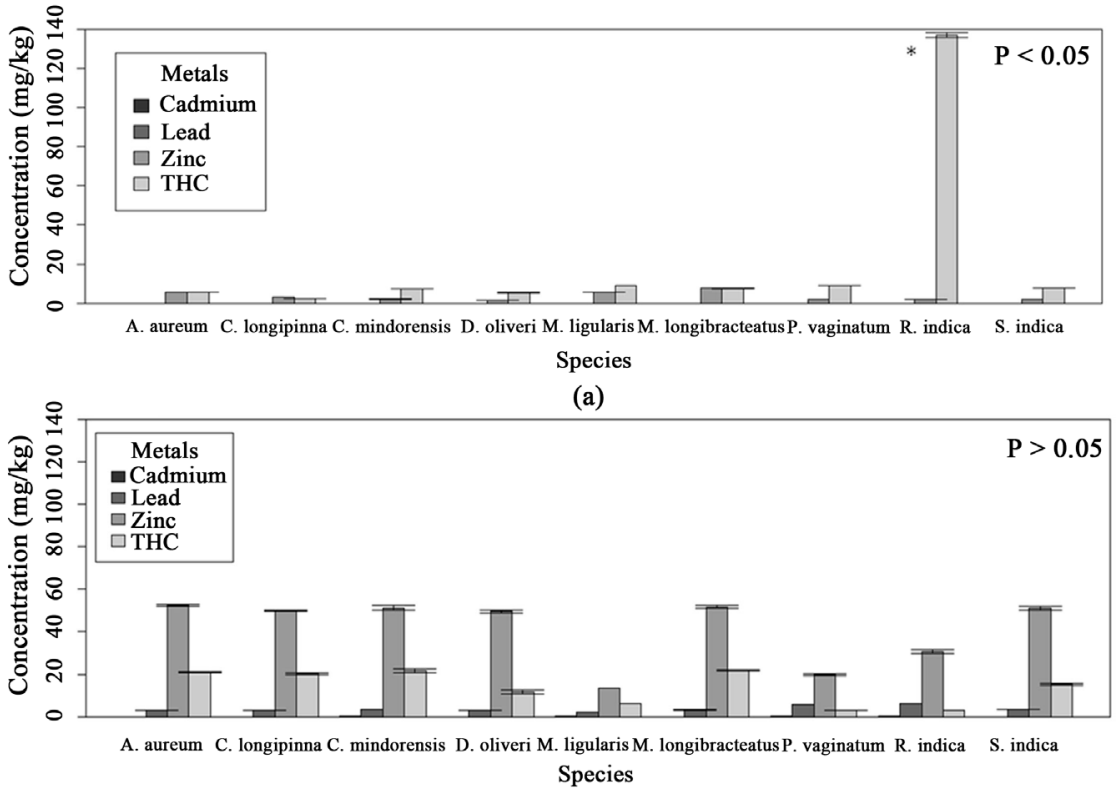

(b)

Figure 3. Mean THC and heavy metal bioaccumulation in (a) soil and (b) plant samples collected in sand filled mangrove forest at Eagle Island, Niger Delta, Nigeria.

Table 2. Mean levels of total hydrocarbon content (THC) and heavy metals $\pm 1 \mathrm{SE}$ in soils collected under weed roots at Eagle Island, Niger Delta Nigeria.

\begin{tabular}{|c|c|c|c|c|}
\hline \multirow{2}{*}{ Species } & \multicolumn{4}{|c|}{ Metals mg/kg } \\
\hline & Cadmium & Lead & Zinc & THC \\
\hline A. areum & $0.002 \pm 0.0004$ & $0.002 \pm 0.0005$ & $5.79 \pm 0.01$ & $5.59 \pm 0.04$ \\
\hline C. longipinna & $0.002 \pm 0.0005$ & $0.002 \pm 0.0005$ & $2.97 \pm 0.01$ & $2.31 \pm 0.03$ \\
\hline C. mindorensis & $0.002 \pm 0.0004$ & $0.001 \pm 0.0000$ & $1.12 \pm 0.01$ & $7.35 \pm 0.05$ \\
\hline D. oliveri & $0.002 \pm 0.0000$ & $0.002 \pm 0.0005$ & $1.54 \pm 0.06$ & $5.46 \pm 0.04$ \\
\hline M. ligularis & $0.002 \pm 0.0005$ & $0.001 \pm 0.0000$ & $5.60 \pm 0.01$ & $8.79 \pm 0.01$ \\
\hline M. longibracteatus & $0.001 \pm 0.0000$ & $0.001 \pm 0.0000$ & $7.67 \pm 0.01$ & $7.55 \pm 0.05$ \\
\hline$P$. vaginatum & $0.002 \pm 0.0005$ & $0.002 \pm 0.0005$ & $1.94 \pm 0.01$ & $8.84 \pm 0.06$ \\
\hline R. indica & $0.001 \pm 0.0000$ & $0.001 \pm 0.0000$ & $1.99 \pm 0.03$ & $137.1 \pm 1.30$ \\
\hline S. indica & $0.002 \pm 0.0005$ & $0.002 \pm 0.0005$ & $1.99 \pm 0.01$ & $7.75 \pm 0.09$ \\
\hline
\end{tabular}


$\mathrm{mg} / \mathrm{kg}) . R$. indica had the overall highest THC concentration $(137.1 \pm 1.30 \mathrm{mg} / \mathrm{kg})$ followed by $P$. vaginatum $(8.84 \pm 0.06 \mathrm{mg} / \mathrm{kg})$ and $M$. ligularis $(8.79 \pm 0.01$ $\mathrm{mg} / \mathrm{kg}$ ). $\mathrm{Cd}$ and $\mathrm{Pb}$ range between $0.001-0.002 \mathrm{mg} / \mathrm{kg}$. The order of importance for the chemicals in soils is $\mathrm{THC}>\mathrm{Zn}>\mathrm{Cd}>\mathrm{Pb}$.

\subsection{Concentration of THC and Heavy Metal in Weed Species}

In contrast, there was no significant difference in THC and heavy metal concentration in the body of the plants $\left(\mathrm{F}_{8,63}=247.0, \mathrm{P}>0.05\right)$. However, there was a significant difference in the concentration of THC and heavy metals $(\mathrm{P}<0.05)$. $\mathrm{Zn}$ and THC had the highest concentration in weed (Table 3). A. areum had the highest $\mathrm{Zn}$ concentration $(52.67 \pm 0.45 \mathrm{mg} / \mathrm{kg}$ ) while $M$. ligularis has the highest THC. Cadmium had the least concentration in weed. The order of importance in weed is $\mathrm{Zn}>\mathrm{THC}>\mathrm{Pb}>\mathrm{Cd}$.

\subsection{Diversity of Weeds in Sand-Filled Mangrove Forests}

A total of fifteen weed species were recorded within the sand filled area of the mangrove forest (Table 4). Most of the species fall under aquatic low land and dry land weeds, which are dicotyledons and monocotyledons [2]. The result indicate that Mariscus longibracteatus had the highest diversity $(-0.366)$ followed by Mariscus ligularis ( -0.339$)$ and Paspalum vaginatum $(-0.270)$. Although, the total diversity $(H=1.5)$ is lower than the weed community in a farmland $(H=$ 2.87) [29]. $M$ longibracteatus is more prominent in sandy mangrove shore as revealed in previous study [30].

\subsection{Plant Species Importance Value}

The result (Table 5) indicate that Mariscus longibracteatus (Family: cyperaceae) are the most abundant $(n=1570)$, and thus have the highest importance value in the study site $\left(I_{v}=58.24\right)$. The order of importance of weed species found in

Table 3. Mean levels of total hydrocarbon content (THC) and heavy metals \pm 1 SE in weed collected Eagle Island, Niger Delta Nigeria.

\begin{tabular}{ccccc}
\hline \multirow{2}{*}{ Species } & \multicolumn{4}{c}{ Metals $\mathrm{mg} / \mathrm{kg}$} \\
\cline { 2 - 5 } & Cadmium & Lead & Zinc & THC \\
\hline A. areum & $0.002 \pm 0.0005$ & $3.01 \pm 0.12$ & $52.67 \pm 0.45$ & $21.09 \pm 0.23$ \\
C. longipinna & $0.002 \pm 0.0005$ & $3.01 \pm 0.13$ & $49.96 \pm 0.07$ & $20.16 \pm 0.38$ \\
C. mindorensis & $0.23 \pm 0.005$ & $3.36 \pm 0.01$ & $51.31 \pm 1.31$ & $21.55 \pm 1.05$ \\
D. oliveri & $0.002 \pm 0.0005$ & $3.05 \pm 0.15$ & $49.55 \pm 0.69$ & $11.61 \pm 0.94$ \\
M. ligularis & $0.26 \pm 0.005$ & $1.87 \pm 0.01$ & $13.44 \pm 0.01$ & $21.85 \pm 0.02$ \\
M. longibracteatus & $0.002 \pm 0.0005$ & $3.11 \pm 0.11$ & $51.72 \pm 0.11$ & $6.30 \pm 0.02$ \\
P. vaginatum & $0.14 \pm 0.005$ & $5.53 \pm 0.01$ & $19.82 \pm 0.01$ & $2.91 \pm 0.40$ \\
R. indica & $0.24 \pm 0.005$ & $5.97 \pm 0.01$ & $30.77 \pm 0.01$ & $3.03 \pm 0.03$ \\
S. indica & $0.001 \pm 0.00$ & $3.45 \pm 0.15$ & $51.18 \pm 0.15$ & $15.21 \pm 0.33$ \\
\hline
\end{tabular}


Table 4. Diversity of plant species in sand fill mangrove forest at Eagle Island, Nigeria.

\begin{tabular}{|c|c|c|c|c|c|}
\hline Scientific name & Common name & Abundance & $p_{i}$ & $\ln \left(p_{i}\right)$ & $p_{i} \times \ln \left(p_{i}\right)$ \\
\hline Mariscus ligularis & NA & 900 & 0.232 & -1.461 & -0.339 \\
\hline Paspalum vaginatum & Seashore paspalum & 525 & 0.135 & -2.002 & -0.270 \\
\hline Reissantia indica & NA & 505 & 0.130 & -2.040 & -0.265 \\
\hline Cyperus mindorensis & White water sedge & 50 & 0.013 & -4.343 & -0.057 \\
\hline Mariscus longibracteatus & NA & 1570 & 0.405 & -0.904 & -0.366 \\
\hline Acrostichum aureum & Mangrove fern & 212 & 0.955 & -0.046 & -0.044 \\
\hline Calamus longipinna & NA & 99 & 0.026 & -3.650 & -0.095 \\
\hline Daniellia oliveri & Ilorin balsam & 5 & 0.001 & -6.908 & -0.007 \\
\hline Stachytarpheta indica & Blue snake weed & 10 & 0.003 & -5.809 & -0.017 \\
\hline Solanum torvum Swartz & Prickly solanum & 3 & 0.001 & -6.908 & -0.007 \\
\hline Emilia praetermissa & Yellow tassel flower & 5 & 0.001 & -6.908 & -0.007 \\
\hline Luffa cylindrica & Loofah & 7 & 0.002 & -6.215 & -0.012 \\
\hline Oldenlandia corymbosa Linn. & NA & 3 & 0.001 & -6.908 & -0.007 \\
\hline Corchorus olitorius L. & Nalta jute & 2 & 0.001 & -6.908 & -0.007 \\
\hline \multirow[t]{2}{*}{ Terminalis catappa } & Indian almond & 4 & 0.001 & -6.908 & -0.007 \\
\hline & SUM & 3880 & 1.00 & & $H=-1.507$ \\
\hline
\end{tabular}

Table 5. Abundance, importance value $\left(I_{V}\right)$, relative density, relative frequency and relative dominance for Eagle Island in the Niger River Delta, Nigeria.

\begin{tabular}{cccccc}
\hline Scientific name & Abundance & $\begin{array}{c}\text { Relative } \\
\text { density }(\%)\end{array}$ & $\begin{array}{c}\text { Relative } \\
\text { frequency }(\%)\end{array}$ & $\begin{array}{c}\text { Relative } \\
\text { dominance }\end{array}$ & $I_{V}$ \\
\hline Mariscus ligularis & 900 & 23.20 & 15.56 & $1.14 \times 10^{-5}$ & 38.75 \\
Paspalum vaginatum & 525 & 23.20 & 13.33 & $4.15 \times 10^{-6}$ & 36.53 \\
Reissantia indica & 505 & 23.20 & 11.11 & $5.55 \times 10^{-5}$ & 34.31 \\
Cyperus mindorensis & 50 & 1.29 & 6.67 & $2.93 \times 10^{-5}$ & 7.96 \\
Mariscus longibracteatus & 1570 & 40.46 & 17.78 & $1.65 \times 10^{-5}$ & 58.24 \\
Acrostichum aureum & 212 & 5.46 & 8.89 & $1.03 \times 10^{-4}$ & 14.35 \\
Calamus longipinna & 99 & 2.55 & 6.67 & $2.25 \times 10^{-5}$ & 9.22 \\
Daniellia oliveri & 5 & 0.13 & 2.22 & $1.83 \times 10^{-4}$ & 2.35 \\
Stachytarpheta indica & 10 & 0.26 & 4.44 & $4.59 \times 10^{-5}$ & 4.70 \\
Solanum torvum Swartz & 3 & 0.08 & 2.22 & $3.71 \times 10^{-5}$ & 2.30 \\
Emilia praetermissa & 5 & 0.13 & 2.22 & $1.14 \times 10^{-5}$ & 2.35 \\
Luffa cylindrica & 7 & 0.18 & 2.22 & $5.02 \times 10^{-6}$ & 2.40 \\
Oldenlandia corymbosa Linn. & 3 & 0.08 & 2.22 & $1.65 \times 10^{-5}$ & 2.30 \\
Corchorus olitorius $\mathrm{L}$. & 2 & 0.05 & 2.22 & $7.36 \times 10^{-6}$ & 2.27 \\
Terminalis catappa & 4 & 0.10 & 2.22 & $5.62 \times 10^{-4}$ & 2.33 \\
SUM & 3880 & & & & \\
\hline & & & & &
\end{tabular}


sand fill soil include; $M$. longibracteatus $>M$. ligularis $>P$. vaginatum $>R$. indica. All species are weed except Acrostichim aureum L., which is classified as a mangrove species under the family of Pteridaceae [31]. They are however, regarded as weed in some places, for instance in Matang, Malaysia [32]. P. vaginatum are also regarded as invasive species [33].

\section{Discussion}

Mangroves are habitat specific, and grow only in swampy soils. This is because most mangrove species apart from $A$. aureum (mangrove fern) cannot grow well in sandy soil because it has low salinity and conductivity (Table 1). Mangrove swamp is one of the largest carbon sequesters in the world [34] [35], this is because of their air purification ability and high productive capability [17]. Swampy soils have higher heavy metal load because of their exposure to oil spillages from oiling activities onshore and offshore. Pollution of the shorelines destroys swampy soils by reducing salinity and destroying microbes within the soil. A known characteristic of mangrove swamp is their ability to carry out decomposition [36], which has made them a biodiversity hot spot [37]. But when human activities of deforestation, sand mining and urbanization degrade the soil it becomes difficult for them to carry out their function as host to numerous soil dwelling organisms. This enables opportunistic invasive species and weeds to come in to colonize the area [38]. In this study, previous sand mining activity destroyed the swampy soil, and in its place sandy soil was deposited, which facilitated the proliferation of weeds [30]. Growth of weeds near or inside mangrove forest is becoming a hallmark of a disturbed forest [27]. The role played by weeds in this study area is not well known but need further studies. However, the result indicates that weeds present in the sand filled area absorbed the soil pollutants. This is shown by Figure 3, where weed concentration of THC and heavy metal was more than that of the soil. It shows that the weeds are acting as bioremediation agents. Mangrove swamp has hydrocarbon utilizing bacteria that degrade pollutant to a less harmful level [39] [40]. The weed species from field observations are acting as host to pollinators such as butterflies, cricket, beetles and mosquitoes, to mangrove; this is a positive role by weeds [41]. However, they can be detrimental to humans by hosting harmful insects and rodents. Field experiences had shown that most mosquitoes that reside in mangrove forest always go to roost on nearby weed and enter the mangroves to feed on animals, which is a negative role because of the proliferation of mangroves parasites in Africa [42].

Most of the weeds found in this study are dominant because they are all aquatic and lowland weeds that benefit from the closeness of the area to a river. The change in the habitat from swampy to sandy soil contributed to the transition from exclusively a mangrove community to a weed community. Loss of mangrove forest as a result of anthropogenic action lead to a loss of the ecosystem services they provide e.g. carbon sequestration, fire wood and basket production 
and fisheries. The weed are not known to provide any significant ecosystem services to the environment apart from being host to some disease parasites, causing bush fires and acting as a nuisance in the environment. The species Mariscus longibracteatus are more dominant because they are aquatic weed that grow in wet grounds in forest zones. They are of the family Cyperaceae [2]. They are large tufted sedge that can grow to about $1 \mathrm{~m}$, and are produced from seeds. Their seeds are tiny and are propagated by wind. They have very prominent spikes on an inflorescence, which sticks to clothing and facilitates dispersal and propagation. This has made them to be found in any environment. Although they are mangrove forest plants, but are introduced through human activities such as logging, sand filling, construction and reclamation. Their presence in a mangrove forest shows that the system had been disturbed by humans.

High concentration of $\mathrm{Zn}$ can be ascribed to increased land runoffs and influx of metal-rich water in the weed root soil giving rise to elevated metal levels. Similarly, elevated levels of metals in weed root soil were observed in Pondicherry Harbor [43]. However, it was found that the total concentrations of all selected heavy metals in the weed root soil were below the critical soil concentration values [44], which reflect the topography and bed rock of the area as the origin of these metals.

\section{Conclusion and Recommendation}

This study is significant because it shows that human activities are major causes of weed invasion of mangrove forest, and weeds are primary successors in disturbed environment. Change in soil condition can lead to the elimination of mangroves due to their affinity for swampy soil rather than sandy soil. To revert the invasion of mangrove forest by foreign weed species, we need to create a protective barrier around the forest to prevent the encroachment of humans. As a way of restoring the mangrove forest there can be a replacement of the sandy soil with swampy soil. Furthermore, weeds can be used to monitor THC and heavy metal contamination of mangrove forest.

\section{Acknowledgements}

I wish to thank my research assistant Mr. Chimezie Brown Iwuji and my undergraduate project students for assistance in collecting the weed and soil samples at the sampling sites.

\section{Conflicts of Interest}

The author declares no conflicts of interest regarding the publication of this paper.

\section{References}

[1] Bouillon, S., Rivera-Monroy, V., Twilley, R.R. and Kairo, J.G. (2009) Mangroves. In: Laīoley, D.d'A. and Grimsditch, G., Eds., The Management of Natural Coastal Car- 
bon Sinks, IUCN, Gland, 53.

[2] Alongi, D.M. (2012) Carbon Sequestration in Mangrove Forest. Carbon Management, 3, 313-322. https://doi.org/10.4155/cmt.12.20

[3] Santini, N.S., Reef, R., Lockington, D.A. and Lovelock, C.E. (2015) The Use of Fresh and Saline Water Sources by the Mangrove Avicennia marina. Hydrobiologia, 745, 59-68. https://doi.org/10.1007/s10750-014-2091-2

[4] Duraimurugan, V. and Jeevanandham, P. (2019) An Assessment of Floral Diversity in the Mangrove Forest of Karaikal, Karaikal District Puducherry Union Territory. International Journal of Research in Social Sciences, 9, 457-475.

[5] Vidya, A.S., Abraham, C.T. and Girija, T. (2004) Weed Spectrum of Pokkali Lands: The Salt Marsh Rice Ecosystem of Kerala. Indian Journal of Weed Science, 36, 157-159.

[6] Ngadiani, N. and Restia, A.S. (2020) Exploring the Type of Ferns (Pteridophyta) to Realize the Wonorejo Surabaya Mangrove Forest Ecology Balance. Journal of Physics. Conference Series, 1469, Article ID: 012114. https://doi.org/10.1088/1742-6596/1469/1/012114

[7] Akobundu, I.O., Ekeleme, F., Ayakwa, C.W. and Ogazie, C.A. (2016) A Handbook of West African Weeds. International Institute of Tropical Agriculture, Ibadan.

[8] Henderson, L. (2011) Mapping of Invasive Alien Plants: The Contribution of the Southern African Plant Invaders Atlas (SAPIA) to Biological Weed Control. African Entomology, 19, 498-503. https://doi.org/10.4001/003.019.0207

[9] Champion, P.D. and Clayton, J.S. (2000) Border Control for Potential Aquatic Weeds. Stage 1. Weed Risk Model. Science for Conservation, 141.

[10] Opuszynski, K. and Shireman, J.V. (2019) Herbivorous Fishes: Culture and Used for Weed Management. CRC Press, Boca Raton, FL. https://doi.org/10.1201/9780429266461

[11] Aye, W.M. and Takeda, S. (2020) Conversion of Abandoned Paddy Fields to Productive Land through Mangrove Restoration in Myanmar's Ayeuarwady Delta. Paddy and Water Environment, 18, 417-429. https://doi.org/10.1007/s10333-020-00791-x

[12] Da Silva, E.F., de Souza, F.R., Martins, L.C., Machado, M.S., Borella, J. and Macahdo, A.F.L. (2020) Phytosociological Characterization of Weed Communities along a Railway Crossing the Atlantic Forest Biome (Brazil). Phytocoenologia. https://doi.org/10.1127/phyto/2020/0355

[13] Mongia, A.D., Lal, K. and Singh, N.T. (2001) Heavy Metal Composition and Some Characteristics of the Soils of Mangrove Forests of Andamans-Indian Islands. Journal of the Indian Society of Soil Science, 49, 412-418.

[14] Vicente-Martorell, J.J., Galindo-Riaño, M.D., García-Vargas, M. and Granado-Castro, M.D. (2009) Bioavailability of Heavy Metals Monitoring Water, Sediments and Fish Species from a Polluted Estuary. Journal of Hazardous Materials, 162, 823-836. https://doi.org/10.1016/j.jhazmat.2008.05.106

[15] Venkateswarlu, V. and Venkatrayulu, C. (2020) Bioaccumulation of Heavy Metals in Edible Marine Fish from Coastal Areas of Nellore, Andhra Pradesh, India. GSC Biological and Pharmaceutical Sciences, 10, 18-24. https://doi.org/10.30574/gscbps.2020.10.1.0244

[16] Ademiluyi, B.O. and Miss Abegunde, C. (2007) Evaluation of Herbicide Spray Programmes and Hoeing for Weed Control in Maize (Zea mays L.) in a South Western Nigerian Location. Research Journal of Agronomy, 1, 38-41.

[17] Numbere, A.O. and Camilo, G.R. (2018) Structural Characteristics, above Ground 
Biomass and Productivity of Mangrove Forest Situated in Areas with Different Levels of Pollution in the Niger Delta, Nigeria. African Journal of Ecology, 56, 917-927. https://doi.org/10.1111/aje.12519

[18] Amusan, A.A. and Adeniyi, I.F. (2005) Characterization and Heavy Metal Retention Capacity of Soils in Mangrove Forest of the Niger delta, Nigeria. Communications in Soil Science and Plant Analysis, 36, 2033-2045. https://doi.org/10.1080/00103620500192225

[19] Lawal, P.O. (2011) Effects of Sand/Gravel Mining in Minna Emirate Area of Nigeria on Stakeholders. Journal of Sustainable Development, 4, 193-199. https://doi.org/10.5539/jsd.v4n1p193

[20] Schwab, A.P., Su, J., Wetzel, S., Pekarek, S. and Banks, M.K. (1999) Extraction of Petroleum Hydrocarbons from Soil by Mechanical Shaking. Environmental Science \& Technology, 33, 1940-1945. https://doi.org/10.1021/es9809758

[21] Aigberua, A. and Tarawou, T. (2018) Speciation and Mobility of Selected Heavy Metals in Sediments of the Nun River System, Bayelsa State, Nigeria. Environmental Toxicology Studies Journal, 2, 1-9.

[22] Logan, M. (2010) Biostatistical Design and Analysis Using R: A Practical Guide. John Wiley \& Sons, Chichester. https://doi.org/10.1002/9781444319620

[23] R Development Core Team (2013) R: A Language and Environment for Statistical Computing. R Foundation for Statistical Computing, Vienna, Austria. https://www.R-project.org

[24] Cintron, G. and Schaeffer-Novelli, S.Y. (1984) Methods for Studying Mangrove Structure. In: Snedaker, S.C. and Snedaker, J.G., Eds., The Mangrove Ecosystem: Research Methods, UNESCO, Paris, 91-113.

[25] Gross, J., Flores, E.E. and Schwendenmann, L. (2014) Stand Structure and Aboveground Biomass of a Pelliciera rhizophorae Mangrove Forest, Gulf of Monitjo Ramsar Site, Pacific Coast, Panama. Wetlands, 34, 55-65. https://doi.org/10.1007/s13157-013-0482-1

[26] Shannon, C.E. and Weiner, W. (1949) The Mathematical Theory of Communication. University of Illinois Press, Urbana.

[27] Abotsi, K.E., Bose, R., Adjossou, K., Deblauwe, V., Rouhan, G., Segla, K.N., Atsri, K.H. and Kokou, K. (2020) Ecological Drivers of Pteridophyte Diversity and Distribution in Togo (West Africa). Ecological Indicators, 108, Article ID: 105741. https://doi.org/10.1016/j.ecolind.2019.105741

[28] Shabala, S. and Pottosin, I. (2014) Regulation of Potassium Transport in Plants under Hostile Conditions: Implications for Abiotic and Biotic Stress Tolerance. Physiologia Plantarum, 151, 257-279. https://doi.org/10.1111/ppl.12165

[29] Nyamwamu, N.C., Karanja, R. and Mwangi, P. (2019) Diversity of Weed Species in Farms Kisii Central Sub-County, Western Kenya. Journal of Horticulture and Plant Research, 6, 11-19. https://doi.org/10.18052/www.scipress.com/JHPR.6.11

[30] Numbere, A.O. (2018) Mangrove Species Distribution and Composition, Adaptive Strategies and Ecosystem Services in the Niger River Delta, Nigeria. In: Sharma, S., Ed., Mangrove Ecosystem Ecology and Function, IntechOpen, London, 17. https://doi.org/10.5772/intechopen.79028

[31] Uddin, S.J., Jason, T.L., Beattie, K.D., Grice, I.D. and Tiralongo, E. (2011) (2S,3S)Sulfated Pterosin C, a Cytotoxic Sesquiterpene from the Bangladeshi Mangrove Fern Acrostichum aureum. Journal of Natural Products, 74, 2010-2013. https://doi.org/10.1021/np2004598 
[32] Chan, H.T. (1989) A Note on the Eradication of Acrostichum aureum Ferns in the Matang Mangroves, Perak, Peninsular Malaysia. Journal of Tropical Forest Science, 2, 171-173.

[33] Fazlioglu, F. and Chen, L. (2020) Introduced Non-Native Mangroves Express Better Growth Performance than Co-Occurring Native Mangroves. Scientific Reports, 10, Article No. 3854. https://doi.org/10.1038/s41598-020-60454-Z

[34] Inoue, T. (2019) Carbon Sequestration in Mangroves. In: Kuwae, T. and Hori, M., Eds., Blue Carbon in Shallow Coastal Ecosystems, Springer, Singapore, 73-99. https://doi.org/10.1007/978-981-13-1295-3_3

[35] Macreadie, P.I., Nielsen, D.A., Kelleway, J.J., Atwood, T.B., Seymour, J.R., Petrou, K., Connolly, R.M., Thomson, A.C., Trevathan-Tackett, S.M. and Ralph, P.J. (2017) Can We Manage Coastal Ecosystems to Sequester More Blue Carbon? Frontiers in Ecology and the Environment, 15, 206-213. https://doi.org/10.1002/fee.1484

[36] Numbere, A.O. and Camilo, G.R. (2017) Mangrove Leaf Litter Decomposition under Mangrove Forest Stands with Different Levels of Pollution in the Niger River Delta, Nigeria. African Journal of Ecology, 55, 162-167.

https://doi.org/10.1111/aje.12335

[37] Wanger, T.C., Ainun, N., Brook, B.W., Friess, D.A., Oh, R.R., Rusdin, A., Smithers, S. and Tjoa, A. (2020) Ecosystem-Based Tsunami Mitigation for Tropical Biodiversity Hotspots. Trends in Ecology \& Evolution, 35, 96-100. https://doi.org/10.1016/j.tree.2019.10.008

[38] Zhang, L. and Shao, H. (2013) Direct Plant-Plant Facilitation in Coastal Wetlands: A Review. Estuarine, Coastal and Shelf Science, 119, 1-6. https://doi.org/10.1016/j.ecss.2013.01.002

[39] Leahy, J.G. and Colwell, R.R. (1990) Microbial Degradation of Hydrocarbons in the Environment. Microbiology and Molecular Biology Reviews, 54, 305-315. https://doi.org/10.1128/MMBR.54.3.305-315.1990

[40] Benget, V.V. and Retnaningrum, E. (2020) Activities and Molecular Characterization of Petroleum Hydrocarbons Degrading Rhizobacteria from Mangrove Plants (Rhizophora sp.) in Kulon Progo, Yogyakarta, Indonesia. Biodiversitas Journal of Biological Diversity, 21, 21-27. https://doi.org/10.13057/biodiv/d210104

[41] Krishnapriya, P.D. and Binoy, C.F. (2020) Abundance and Diversity of Soil Arthropods in a Tropical Deciduous Forest and Mangrove Forest of Kerala, India. Entomon, 45, 69-74.

[42] Sevidzem, S.L., Pamba, R., Koumba, A.A., Zinga-Koumba, C.R., Mbouloungou, A., Yacka, L.L., Djogbenou, L.S., Mavoungou, J.F. and M'Batchi, B. (2020) Typology of Breeding Sites and Species Diversity of Culicids (Diptera: Culicidae) in Akanda and Its Environs (North West, Gabon). European Journal of Biology and Biotechnology, $1,1-6$.

[43] Senthilnathan, S. and Balasubramanian, T. (1999) Distribution of Heavy Metals in Estuaries of Southeast Coast of India. Indian Journal of Marine Science, 26, 95-97. http://nopr.niscair.res.in/handle/123456789/36157

[44] Alloway B.J. (1990) Heavy Metals in Soils. John Wiley \& Sons, Inc., New York. 